Vol. 8, Issue 10, October 2021

DOI: 10.17148/IARJSET.2021.81021

\title{
Infrared and Ultraviolet Spectroscopic analysis of ethanolic leaf extract of Thevetia peruviana (Pers.) K. Schum [Thevetia orange]
}

\author{
Krati Ghavri ${ }^{1}$, Madhavi Adhav ${ }^{2}$ \\ ${ }^{1,2}$ Department of Botany, P.M.B. Gujarati Science College, Indore (M.P.)
}

\begin{abstract}
Thevetia peruviana (Pers.) K. Schum is one of the important medicinal as well as ornamental plant belongs to the family Apocynaceae and commonly called as yellow oleander. The cardiac glycosides obtained from bark, kernals, flowers are useful for heart diseases. The present investigation was confined to Thevetia peruviana (Pers.) K. Schum with Thevetia Orange Leaf. The results of phytochemical screening of ethanolic leaf extract shows the presence of alkaloids, flavanoids, glycosides - cardiac glycosides, phenolic compounds, tannins , phytosterols ,terpenoids, carbohydrates, proteins and amino acids. The fixed oils, fats, gums and mucilages were totally absent. The UV and IR spectroscopy of ethanolic leaf extract of Thevetia orange shows the presence of carbonyl groups, $\beta-$ diketones, aldehydes, ketones ,amides, lactams, sulfur compounds, aromatic compounds, nitro compounds, indole alkaloidaricine, sarpagine and flavanoids - flavones, flavanones, chalcones, quercetin, sodium salt of quercetin 5'sulfonic acid [NaQSA], myricetin and fistein. The above mention bioactive compounds are responsible for medicinal properties of the plant.
\end{abstract}

Keywords: Thevetia peruviana (Pers.) K. Schum, Phytochemical screening, Ultraviolet and Infrared Spectroscopy.

\section{INTRODUCTION}

The medicinal plants have been the main source of drugs used in traditional system of medicine. Other than that, a plenty of modern drug molecules are also originated from natural products. These herbal products are relatively safe in contrast to the synthetic molecules, which carry a lot of side effects with them.

Before the establishment of modern medicine, traditional practices like Ayurveda, Yunani, Shidda and Homeopathy have been mostly relying on plant products, as a source for drugs.

Thevetia peruviana (Pers.) K. Schum is a small tree, 15-20 ft. high belongs to the family Apocynaceae originally a native of America and West Indies. Leaves are simple, linear - lanceolate and whorled. All parts of this plant abound in a milky juice which is highly poisonous. (Chopra et al.,1984).

The plant is bitter, pungent, acrid, astringent to the bowels, useful in urethral discharges , worms, skin diseases , leucoderma ,wound piles ,eye trouble, itching ,fever and bronchitis.(Kirtikar and Basu,1984).

The cardiac glycosides obtained from bark, kernals and flowers are useful for heart diseases. (Prajapati et al.,2007) The root of this plant are made into a paste and applied to tumours. (Singh and Dey,2005). The leaves are emetic and purgative. Leaf decoction is given to prevent conception.

The purified glycosides thevetin extracted from the seed is prescribed as a cardio tonic drug. Seeds used as an abortifacient and purgative in rheumatism and dropsy; also used as an alexeteric. Diluted latex is given to treat irregular menstruation.(Ambasta,1986; Kaushik and Dhiman ,1999; Retnam and Martin,2006). (Fig No. 1). 


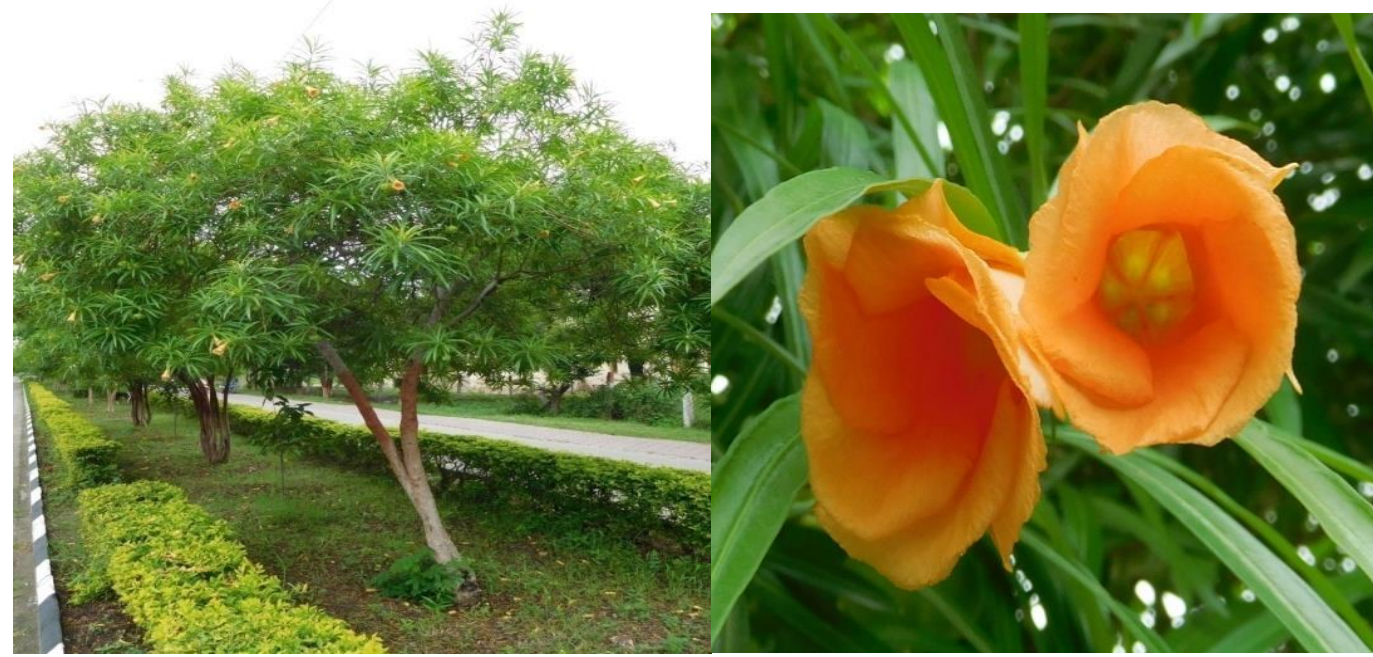

Fig 1: Thevetia peruviana (Pers.) K. Schum [Thevetia Orange]

\section{MATERIAL AND METHODS}

\section{Collection of Plant Material}

Plant materials (Thevetia Orange leaf) of Thevetia peruviana (Pers.) K. Schum were collected from Devi Ahilya Vishwavidyalaya campus, Indore. The collected plant materials were identified with the help of Flora of Madhya Pradesh. (Mudgal et al.,1997).

\section{Extraction}

To obtain ethanolic extract $100 \mathrm{gm}$. of shade dried plant material was extracted with $500 \mathrm{ml}$. of ethanol (95\%) in "Soxhlet Extraction Apparatus. Finally the prepared plant material was macerated with water for 24 hrs. to obtain aqueous extract. Each extract was concentrated by distilling off the solvent (Kokate, 1994 and Kokate et al.,1993).

\section{Preliminary Phytochemical Screening}

The extract thus obtained was than subjected to preliminary phytochemical screening for identification of various plant constituents by methods suggested by (Finar,1962 ; Farnsworth, 1966; Harborne,1973; Harborne et al.,1979).

\section{Spectral studies}

To find out the alkaloids, flavanoids, chromophoric groups and functional groups present in the extract. Spectral studies were carried out by Ultra violet and Infra-red Spectroscopy. (Bohm,1998; Dyer,1994; Dutta,2000; Harborne et al.,1975 ;Hencezkowski et al.,2001; Manaske, 1960;Silverstein et al., 1991; Silverstein and Webster ,2012).

\section{OBSERVATIONS AND DISCUSSION}

\section{Phytochemical screening}

The leaf extract of Thevetia Orange reveals the presence of alkaloids, flavanoids, glycosides-cardiac glycosides, phenolic compounds, tannins, phytosterols, carbohydrates, saponins, terpenoids, proteins and amino acids was noted in the observation Table, while fixed oils, fats, gums and mucilages were found absent.Among the carbohydrates glucose, fructose and lactose and starch were reported in the ethanolic leaf extracts, while galactose was totally absent.(Table No. 01).

Table No.1: Phytochemical screening of ethanolic leaf extract of Thevetia peruviana (Pers.)K. Schum [Thevetia Orange]

\begin{tabular}{|l|l|l|}
\hline S. No. & Plant Constituents Test/Reagents & Results \\
\hline 1. & Alkaloids & \\
\hline & Mayer's reagent & + \\
\hline & Dragendorff's reagent & + \\
\hline & Hager's reagent & + \\
\hline & Wagner's reagent & + \\
\hline 2. & Carbohydrates & + \\
\hline & Molish's reagent & + \\
\hline & Benedict's reagent & + \\
\hline & Fehling solution & \\
\hline 3. & Types of Carbohydrates & \\
\hline
\end{tabular}


International Advanced Research Journal in Science, Engineering and Technology

Vol. 8, Issue 10, October 2021

DOI: 10.17148/IARJSET.2021.81021

\begin{tabular}{|c|c|c|}
\hline & Glucose & + \\
\hline & Fructose & + \\
\hline & Galactose & - \\
\hline & Lactose & + \\
\hline & Starch & + \\
\hline \multirow[t]{2}{*}{4.} & Phytosterols & \\
\hline & Liebermann-Burchard's test & + \\
\hline \multirow[t]{2}{*}{5.} & Terpenoids & \\
\hline & Salkowski reaction & + \\
\hline \multirow[t]{2}{*}{6.} & Fixed oils and fats & \\
\hline & Spot test & - \\
\hline \multirow[t]{2}{*}{7.} & Saponins & \\
\hline & Foam test & + \\
\hline \multirow[t]{2}{*}{8.} & Phenolic compounds & \\
\hline & Ferric chloride solution & + \\
\hline \multirow[t]{2}{*}{9.} & Tannins & \\
\hline & Lead acetate solution & + \\
\hline \multirow[t]{3}{*}{10.} & Proteins & \\
\hline & Biuret test & + \\
\hline & Xanthoprotic test & + \\
\hline \multirow[t]{2}{*}{11.} & Amino acids & \\
\hline & Ninhydrin reagent & + \\
\hline \multirow[t]{2}{*}{12.} & Gums and mucilages & \\
\hline & Alcoholic precipitation & - \\
\hline \multirow[t]{3}{*}{13.} & Flavanoids & \\
\hline & Shinoda test & + \\
\hline & Lead acetate test & + \\
\hline \multirow[t]{2}{*}{14.} & Cardiac glycosides & \\
\hline & Killer kiliani test & + \\
\hline
\end{tabular}

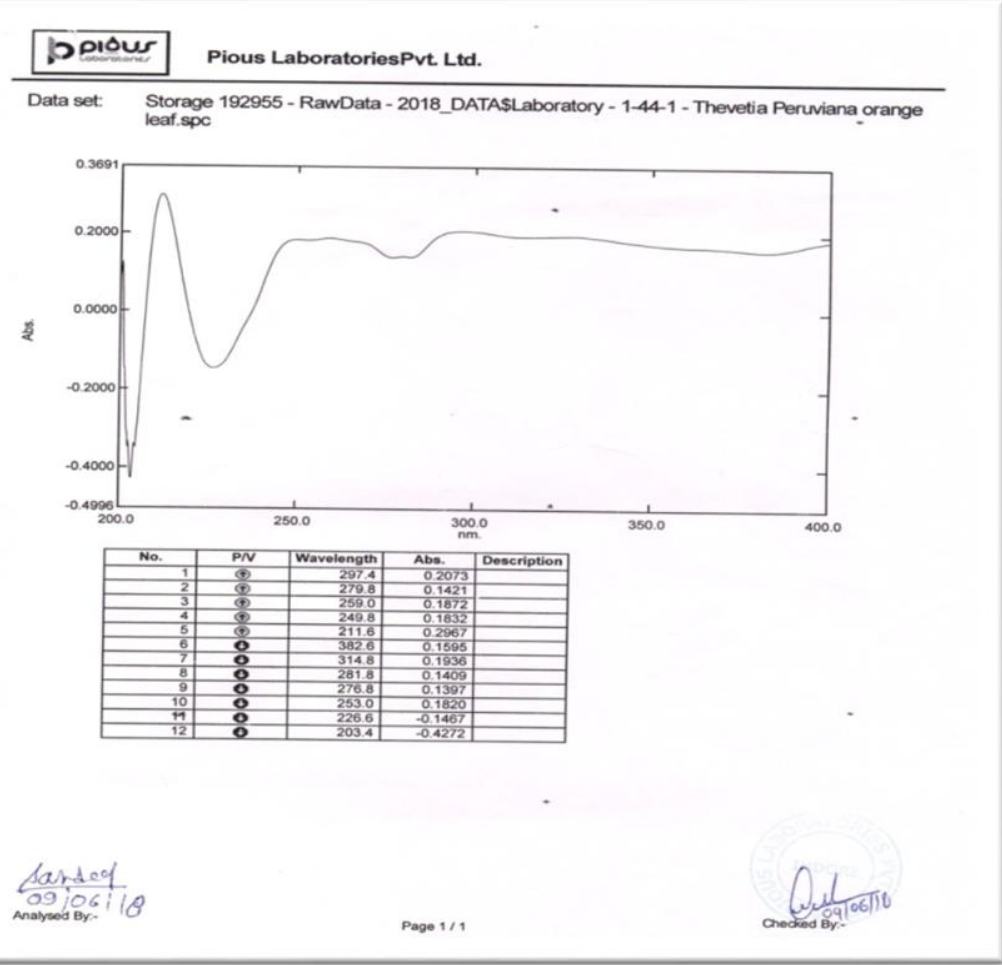

Fig 2: UV spectrum of ethanolic leaf extract of Thevetia Orange 


\section{International Advanced Research Journal in Science, Engineering and Technology}

Vol. 8, Issue 10, October 2021

\section{DOI: $10.17148 /$ IARJSET.2021.81021}

UV Spectroscopy of ethanolic leaf extracts of Thevetia peruviana (Pers.) K. Schum [Thevetia Orange]

The UVspectrum of Thevetia peruviana (Pers.) K. Schum of orange leaf shows weak absorption at $297 \mathrm{~nm}$ is due to the presence of carbonyl group , $\mathrm{C}=\mathrm{S}$, sulfur containing group, thiophene and flavonoid-flavanone .

The band $280 \mathrm{~nm}$, reveals the presence of carbonyl group , $\mathrm{C}=\mathrm{S}$, sulfur containing group,1- phenyl -1,3- butadiene, Indole alkaloids (aricine, sarpagine) and flavone and chalcones type of flavanoid. Another band at $259 \mathrm{~nm}$ confirms the presence of $\alpha, \beta$ - unsaturated ketones, pyridine, $\beta$ - diketones and $\mathrm{C}=\mathrm{S}$, sulfur containing group .It also shows the presence of

+ Present, - Absent

flavone and chalcones type of flavanoid. The strong band is seen at $212 \mathrm{~nm}$. which indicates methyl vinyl

ketone, amides and lactams.

From the UV spectroscopy it is concluded that two types of Indole alkaloids (aricine, sarpagine) and three types of flavonoids viz. flavone, flavanones and chalcones are present. (Fig No. 2, Table No. 2).

Table No. 2 : UV spectroscopy of ethanolic leaf extract of Thevetia Orange

\begin{tabular}{|l|l|l|l|l|l|}
\hline $\begin{array}{l}\text { S. } \\
\text { No. }\end{array}$ & $\begin{array}{l}\text { Wave } \\
\text { length } \\
\text { nm }\end{array}$ & Abs. & $\begin{array}{l}\text { Types of } \\
\text { Alkaloids }\end{array}$ & Chromophoric group & $\begin{array}{l}\text { Types of } \\
\text { Flavonoid } \\
\text { s }\end{array}$ \\
\hline 1. & 297 & 0.2073 & & $\begin{array}{l}\text { C=S, sulfur containing groups and } \\
\text { thiophene }\end{array}$ & Flavanone \\
\hline 2. & 280 & 0.1421 & $\begin{array}{l}\text { aricine, } \\
\text { sarpagine, }\end{array}$ & $\begin{array}{l}\text { carbonyl group , C=S, sulfur } \\
\text { containing groups, } 1-\quad \text { phenyl -1,3- } \\
\text { butadiene }\end{array}$ & $\begin{array}{l}\text { Flavone, } \\
\text { Chalcones }\end{array}$ \\
\hline 3. & 259 & 0.1832 & - & $\begin{array}{l}\alpha, \beta-\text { unsaturated ketones ,pyridine, } \beta \\
- \text { diketones and C=S sulfur } \\
\text { containing group }\end{array}$ & $\begin{array}{l}\text { Flavone, } \\
\text { Chalcones }\end{array}$ \\
\hline 4. & 212 & 0.2967 & - & $\begin{array}{l}\text { methyl vinyl ketone ,amides and } \\
\text { lactams ans }\end{array}$ & - \\
\hline
\end{tabular}

IR Spectroscopy of ethanolic leaf extracts of Thevetia peruviana (Pers.) K. Schum [Thevetia Orange]

The IR spectrum of orange leaf shows the peak at $617 \mathrm{~cm}^{-1}$ is due to the presence of sulfur compound, sulfides and alkynes , C-H bending. The sharp peak at $879 \mathrm{~cm}^{-1}$ indicates the presence of aromatic substitutions, C-H bending vibration and gem - disubstituted olefinic groups and quercetin type of flavanoid..The small peak at $972 \mathrm{~cm}^{-1}$ only shows the presence of alkene, $\mathrm{C}$-H bending.

A very sharp peak at $1041 \mathrm{~cm}^{-1}$ shows the presence of sulfur compounds ,sulfoxides, $\mathrm{S}=\mathrm{O}$ stretching , thiocarbonyl group and sodium salt of quercetin 5' sulfonic acid (NAQSA). Sharp peak at $1088 \mathrm{~cm}^{-1}$ is due to the presence of sulfur compounds, thiocarbony group and sodium salts of quercetin -5 sulfonic acid (NaQSA) type of flavanoid.

The shoulder peak at $1149 \mathrm{~cm}^{-1}$ again confirms the presence of sulfur compound, sulfones and thicarbonyl group. The peak at $1273 \mathrm{~cm}^{-1}$ shows the presence of aromatic, amines, C-N vibrations and ketones .

The small peak at $1327 \mathrm{~cm}^{-1}$ corresponding to aromatic amines, gem dimethyl group sulfur compounds, sulfones and sulfonamides, C-N vibrations ,nitro compounds and flavanoid -myricetin . The shoulder peak $1389 \mathrm{~cm}^{-1}$ and $1420 \mathrm{~cm}^{-1}$ shows the presence of sulfur compound sulfites, $\mathrm{S}=\mathrm{O}$ stretching and alkene, $\mathrm{C}-\mathrm{H}$ bending . The peak at $1450 \mathrm{~cm}^{-1}$ indicates the presence of carbonyl group and fisetin type of flavanoid.

Appearance of sharp peak at $1651 \mathrm{~cm}^{-1}$ is due to the presence of amides, $\beta$ - keto ester / enolic, seven member ring , carbonyl stretching vibrations, quinones and lactams and flavones type of flavanoid, the overtone peaks at $2129 \mathrm{~cm}^{-1}$ and $2152 \mathrm{~cm}^{-1}$ indicates the presence of alkyne, monosubstituted, $-\mathrm{N}=\mathrm{C}-\mathrm{N}-$ stretching vibrations and diamides.

The small peak at $2893 \mathrm{~cm}^{-1}$ and $2932 \mathrm{~cm}^{-1}$, the sharp peak at $2978 \mathrm{~cm}^{-1}$ and the hump peak at $3286 \mathrm{~cm}^{-1}$ shows the presence of $\beta$ - diketones, $\mathrm{O}-\mathrm{H}$ stretching, carboxylic acid / intermolecular hydrogen bonding , $\mathrm{C}-\mathrm{H}$ stretching and aldehydes .

The broadening of peak hump at $3340 \mathrm{~cm}^{-1}$ and $3364 \mathrm{~cm}^{-1}$ reveals the presence of aromatic , amines , N-H stretching and primary sulfonamides.From the IR spectroscopy five types of flavanoids are concluded viz. quercetin fisetin, flavone, sodium salts of quercetin -5 sulfonic acid (NaQSA) and myricetin in Thevetia orange leaf. (Fig No. 3, Table No. 3). 
International Advanced Research Journal in Science, Engineering and Technology

Vol. 8, Issue 10, October 2021

DOI: $10.17148 /$ IARJSET.2021.81021

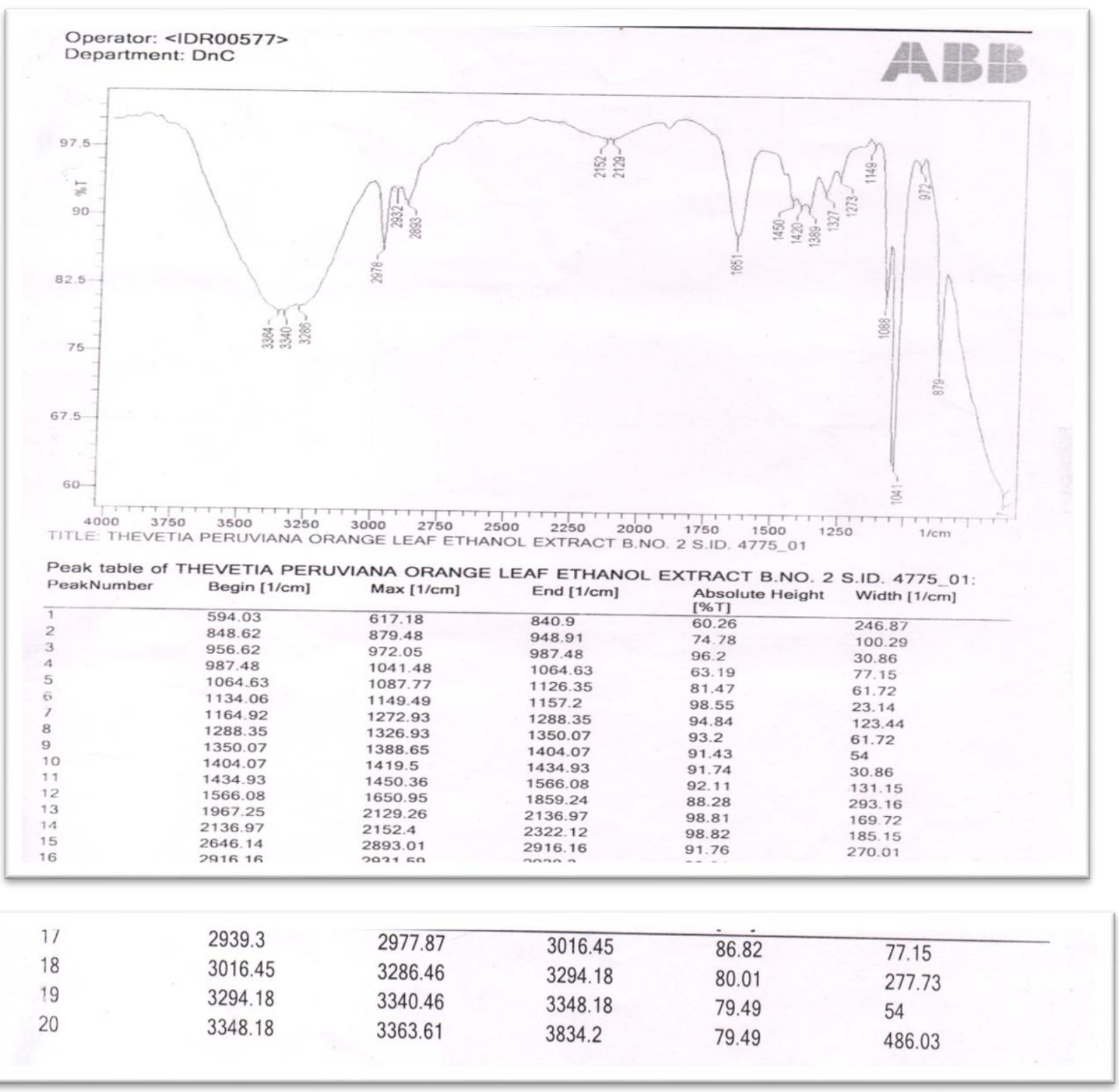

Fig 3: IR spectrum of ethanolic leaf extract of Thevetia Orange

Table 3: IR spectroscopy of ethanolic leaf extract of Thevetia peruviana (Pers.) K. Schum [Thevetia Orange]

\begin{tabular}{|l|l|l|l|}
\hline $\begin{array}{l}\text { Peak } \\
\text { No. }\end{array}$ & $\begin{array}{l}\text { Peak } \\
\text { cm-1 }\end{array}$ & $\begin{array}{l}\text { Types of } \\
\text { flavanoid }\end{array}$ & Functional group \\
\hline 1. & 617 & & Alkynes,C-H bending, Sulfur compound,Sulfites \\
\hline 2. & 879 & - Quercetin & $\begin{array}{l}\text { Aromatic substitution, C-H } \\
\text { bending vibration,gem-disubstituted olefinic group }\end{array}$ \\
\hline 3. & 972 & & Alkene,C-H bending \\
\hline 4. & 1041 & NaQSA & Sulfur compound- Sulfoxides, S=O stretching, Thiocarbonyl group \\
\hline 5. & 1088 & NaQSA & Sulfur compound, Thiocarbonyl group \\
\hline 6. & 1149 & - & Sulfur compound,sulfones, Thiocarbonyl group \\
\hline
\end{tabular}




\section{International Advanced Research Journal in Science, Engineering and Technology}

Vol. 8, Issue 10, October 2021

DOI: $10.17148 /$ IARJSET.2021.81021

\begin{tabular}{|c|c|c|c|}
\hline 7. & 1273 & . & Aromatic, Amines,C-N vibrations, Ketones \\
\hline 8. & 1327 & Myricetin & $\begin{array}{l}\text { Gem-dimethyl group, } \\
\text { Sulfonamide,Sulfones, Aromatic, amines, C-N vibrations , nitro } \\
\text { compound }\end{array}$ \\
\hline 9. & 1389 & _ & Sulfur compound, Sulfites, $\mathrm{S}=\mathrm{O}$ stretching \\
\hline 10. & 1420 & - & Sulfur compound, Sulfites, $\mathrm{S}=\mathrm{O}$ stretching, alkene, $\mathrm{C}-\mathrm{H}$ bending \\
\hline 11. & 1450 & Fisetin & Carbonyl group \\
\hline 12. & 1651 & Flavone & $\begin{array}{l}\text { Amides, } \beta \text {-keto ester/ enolic,seven member ring or compound, carbonyl } \\
\text { stretching vibrations, quinones(ketones),lactams }\end{array}$ \\
\hline 13. & 2129 & - & $\begin{array}{l}\text { Alkyne monosubstituted } \\
-\mathrm{N}=\mathrm{C}=\mathrm{N}-\text { stretching vibrations, Diimides }\end{array}$ \\
\hline 14. & 2152 & & $\begin{array}{l}\text { Alkyne monosubstituted } \\
-\mathrm{N}=\mathrm{C}=\mathrm{N} \text { - stretching vibrations, Diimide }\end{array}$ \\
\hline 15. & 2893 & & Carboxylic acid, $\beta$-diketones, $\mathrm{O}-\mathrm{H}$ stretching, aldehydes, $\mathrm{C}-\mathrm{H}$ stretching \\
\hline 16. & 2932 & - & Carboxylic acid, $\beta$-diketones, $\mathrm{O}-\mathrm{H}$ stretching \\
\hline 17. & 2978 & - & Carboxylic acid, $\beta$-diketones, $\mathrm{O}$-H stretching \\
\hline 18. & 3286 & - & Carboxylic acid, $\beta$-diketones, $\mathrm{O}$-H stretching \\
\hline 19. & 3340 & - & aromatic,amines, $\mathrm{N}-\mathrm{H}$ stretching vibrations, primary sulfonamides \\
\hline 20. & 3364 & _- & aromatic,amines, $\mathrm{N}-\mathrm{H}$ stretching vibrations, primary sulfonamides \\
\hline
\end{tabular}

\section{CONCLUSION}

From the present investigation it may be concluded that chromophoric and functional groups, alkaloids, flavanoids, cardiac glycosides, phenolic compounds, tannins, phytosterols, terpenoids and saponins are identified which are responsible for medicinal properties. Further investigations are required in order to test other bioactivities with the aim of increasing the medicinal utility of Thevetia peruviana (Pers.) K. Schum [Thevetia Orange] plant.

\section{ACKNOWLEDGEMENT}

We wish to express our sincere gratitude to the Principal and Head of the Department of Botany,

P. M .B. Gujarati Science College, Indore, for provided full research laboratory facilities throughout our work.

\section{REFERENCES}

1. Ambasta, S.P. (1986).The useful plants of India. Publications and Information Directorate, CSIR, New Delhi, India.636.

2. Aziz, S.; Mitu, T.K.; Farhana, S. (2018).Phytochemical Screening, UV and FT-IR Analysis of Ethanolic Seed Extract of Santalum rubrum International Journal of Pharma Research and Health Sciences, 6 (5): 2788-91.

3. Bohm ,B.A.(1998). Introduction to Flavonoids. Harwood Academic Publishers, Canada. 200-202.

4. $\quad$ Chopra , S.R.N.; Badhwar, R. L. and Ghosh ,S. (1984).Poisonous Plants of India. Academic Publishers ,Jaipur, India .1:665-668.

5. Dutta ,M. (2000). Infrared Spectroscopy.IVY Publishing House, Sarup and Sons.

6. Dyer John, R.(1994) Application of absorption spectroscopy of organic compounds. Prentice hall of India private limited, New Delhi, India.5-53.

7. Farnsworth, N. Manske, 1960.(1996).Biological and Phytochemical Screening of Plants. J. pharm. Sci. 55:225-276.

8. $\quad$ Finar ,L .L. (1962).Organic chemistry, Lonngman, Green Grosvent Street, London.

9. Harborne, J.B. (1973). Phytochemical methods, Chapman and Hall Ltd. London.49-188.

10. Harborne, J.B.; Mabry T.J.; Mabry, H. (1975) .The flavonoids. First Edition. Chapman and Hall Ltd.46.

11. Harborne,J.B.; Mabry,T.J.; Mabry, H. (1979).The flavonoids .Chapman and Hall International Edition, London.

12. Heneczkowski,M.; Kopacz,M. ;Nowak D.; Kuzniar ,A. (2001).Infrared spectrum analysis of some flavonoids. Acta poloniae pharmaceutica-Drug research, 58(6):415-420.

13. K.,Kalaichelvi and S.M. Dhivya. (2017).Screening of phytoconstituents, UV-VIS Spectrum and FTIR analysis of Micrococca mercurialis (L.) Benth. The International Journal of Herbal Medicine. 5(6): 40-44. 


\title{
International Advanced Research Journal in Science, Engineering and Technology
}

\author{
Vol. 8, Issue 10, October 2021
}

\section{DOI: $10.17148 /$ IARJSET.2021.81021}

14. Kaushik, P. and Dhiman, A.K.(1999).Medicinal plants and raw drugs of India. Bishen Singh Mahendra pal Singh publication, Dehradun, India. 352-353.

15. Kirtikar,K.R.and Basu,B.D.(1981).Indian medicinal plants. International book distributors.2: 1553-1556

16. Kokate, C.K;Purohit.A.P.;Gokhale,B.B.(1993). Pharmacognosy, Twelth Edition, Nirali prakashan, Pune, India. 90-93.

17. Kokate,C.K. (1994).Practical pharmacognosy ,Fourth Edition, Vallabh prakashan, Delhi,India.107-111.

18. Malviya, S. and Dwivedi,P.(2019). Extracts of Ailanthus excels an Essential Medicine in Ayurveda: Pharmacological evaluation and preliminary screening of phytochemicals. Journal of Drug Delivery and Therapeutics. 9(1):84-87.

19. Manske, R.H.F. (1960).The Alkaloids. Chemistry and Physiology .Academic Press Inc. London, Ltd.7.

20. Mudgal,V.;Khanna,K.K.;Hajra,P.K.(1997) Flora of Madhya Pradesh. The director, Botanical Survey of India, Calcutta.59-60.

21. Prajapati,N.D.;Purohit,S.S.;Sharma,A.K.;Kumar,T.(2007).A Handbook of medicinal plants.Agrobios,Jodhpur,India.511-512.

22. Retnam; Raveendra, K.;Martin ,P. (2006) Ethnomedicinal plants. Agrobios publication, India.

23. Silpa M.; Joghee, S. and Hamsalakshmi (2020). A phytochemical study on Eupatorium glandulosum. Asian J Pharm Clin Res, 13 (1):77-

80.

24. Silverstein, Robert M.; Bassler, G. Clayton and Morrill, Terence C.(1991). Spectrometric identification of organic compound fourth edition. John wiley and Sons publication .305- 331.

25. Silverstein, Robert M. and Webster, Francis X.( 2012). Spectrometric identification of organic compound sixth edition. John wiley and Sons publication .71-143.

26. Singh M.P. and Dey S. (2005).Indian medicinal plants. Satish serial publishing house, Delhi, India. 